\title{
The Political Participation Rate of Starter Voter in Mayor Election 2018 in Cikole District Sukabumi City
}

\author{
Ike Rachmawati ${ }^{1}$, Dian Purwanti ${ }^{2}$ \\ \{ike_rachmawati1@yahoo.com ${ }^{1}$, purwantidian75@yahoo.com ${ }^{2}$ \} \\ Universitas Muhammadiyah Sukabumi, Indonesia ${ }^{1,2}$
}

\begin{abstract}
Beginner for starter Voters are voters for the first time to follow the stages of the general election, in this case the election of Mayor and Deputy Mayor of Sukabumi. One indicator of the success of political education is the level of participation or the participation of the voters. As a first-time voter, many factors that influence the direction of choice. This study suggests matters related to the participation of voters in the election of Mayor and Deputy Mayor of Sukabumi. Political sociology states that political participation can be divided into three dimensions, namely: 1) active participation; 2) passive participation; 3) participation inactive (inactive). This study used a qualitative approach with the method of collecting data through observation, interviews, documentation and triangulation. The final conclusion is that the participation of voters influenced by the propaganda of the election committee, a private first-time voter and the environment. Further research needs to be done further to learn more about other aspects in more depth. While efforts to increase the participation of voters needed family support, improved data and stimulus voters as stimuli for the voters.
\end{abstract}

Keywords: Beginner Voters, Election Commission, Political Participation.

\section{Introduction}

Political participation in a democracy is an indicator of the implementation of the organization of supreme state power that involves people directly in elections. According to article 1, paragraph (22) of UU Number 10 In 2008, the voters are Indonesian citizens who have reached the age of 17 years or more or has/have been married, then article 19 paragraph (1 and 2) of UU Number 10 in 2008 explained that the voters have the right to vote is a citizen of Indonesia that are listed by the organizers of the election in the list of voters and on the voting day was even aged 17 or older or who are or have been married. Thus, voters are Indonesian citizens who have been registered by the organizer of the elections in the voter list.

Voters are first time voters who voted in the general election. Voters who just entered their teens have a political understanding is lacking and very prone to be influenced by people who have interest in and ignorance of politics. The main character of the voters, strongly influenced by the social environment, especially the environment of the family be the deciding factor. Political education as a whole has not yet touched the voters, so the voters on election day more to follow family choice.

Sukabumi city has three times held direct elections of Mayor (Walikota) and Deputy Mayor (Wakil Walikota), namely in 2008, 2013 and now 2018. The total number of voters in 2013 as many as 27034 of the total number of voters in the DPT (Fixed Voter List) and most first-time 
voters in 2013 in the District Warudoyong, but the researchers took Cikole locus in the district because of its position in the midst of the city and also to the many people who even from outside the area in the district of Sukabumi stay Cikole. As well seen from the figures also the District Cikole white group (not choose) has the highest rate of white group. Number of voters in the district as much as 4,706 Cikole consisting of 2,376 males and 2,340 females.

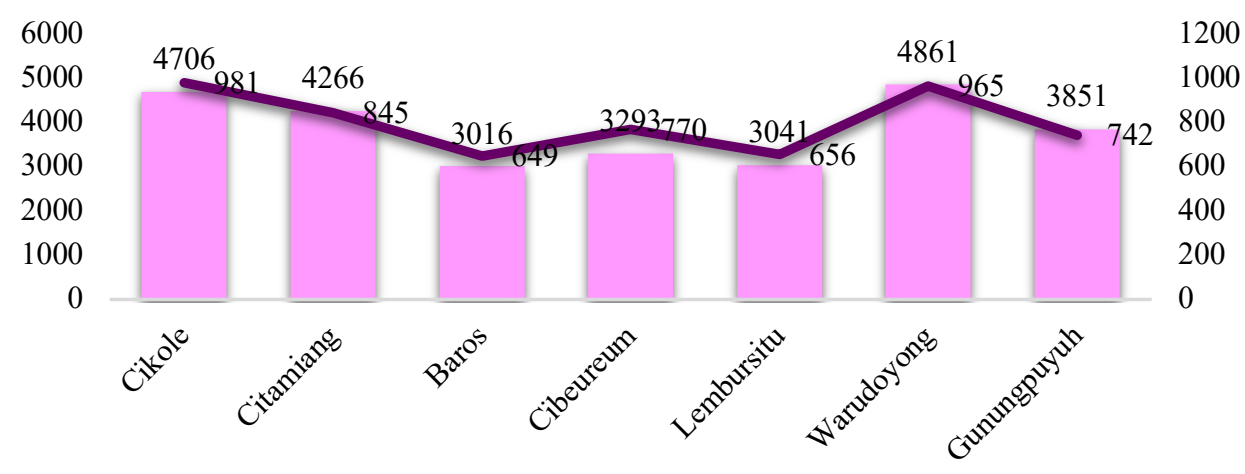

Fig. 1. Voters Political Participation Starter 2018 (Source: General Election Commissions of Sukabumi)

From the observation of the early researchers saw some of the phenomenon on the political participation of voters such as:

a) Lack of political education

b) The lack of first-time voters caring attitude towards political activity,

c) Unfavorable political environment at the time the decision was issued an open plenary result.

\section{Literature Review}

Participation is also understood as participating or participating which has been understood by the people of Indonesia. Many public events, both political and non-political dimension can be held either for their participation or the participation of citizens. In any event the general elections (legislative, presidential, regional heads and village heads) in Indonesia, the people designing sites and locations such election so that people interested in coming to the place of voting. Such activity is understood as participation [1][2].

Imawan [3] reveals that the participation of the most important features of democracy. Without democracy impossible products of government policies to satisfy the justice of its citizens. Contained three kinds of aspects of participation, the first is the existence of equal opportunity for every citizen to express the views and interests in the process of policy formulation, the second is their chance to fight for the views and interests of the both individually and together, the third is the same treatment, especially of the ruling government, against the views and interests championed by citizens.

Politics is an event, activity, organization or process involving the government and society in a country in making policies or decisions for the welfare and survival of the community, state and nation. In Damsar [1], Maurice Duverger (1082) noticed that the ambivalent nature of politics, which is on one side of politics is a conflict for power, in which individuals or groups 
who hold it tends to maintain its dominance over society. While individuals or groups in power are trying to oppose even seize it. On the other side of politics as an attempt to enforce order and justice.

Politics can be understood as a process of formation and distribution of power in society, among others intangibles decision making process, especially in the country, can also be understood as a process of interaction between the authorities and the ruled [4]. With the political sense as it has been stated that the policy is understood as the power, authority, public life, government (government), state (state), conflict and conflict resolution, policy, decision making, and distribution or allocation.

Political participation is the involvement of individuals until at various levels within the political system. Rush and Althoff argued in the Maran [5] political participation is considered as a result of political socialization. But it is necessary also noted that political participation also affect the political socialization [6]. Without political participation, political socialization cannot run.

According Setiadi and Kolip [4] the political participation is divided into five forms, namely: 1) activities related to the elections, 2) lobbying, 3) activities of political organizations, 4) contacts with government officials makers and implementers of decisions, and 5) influence the political process by force.

Lane in Handoyo [7] states that the political participation of at least four functions, namely: a) as a means of pursuing economic needs, b) as a means of satisfying a need for social adjustment, c) the pursuit of special values, d) meet the needs of unconscious and certain psychological needs. Of the four functions can be seen that the political participation serves to attempt to fulfill the needs for perpetrators of political participation in this case is the community.

Damsar [1] suggests that the increase or decrease in the level of political participation certainly influenced by factors that influence it. There are two driving factors for the strengthening of political participation. First, the increased knowledge of the people's political participation. Second, the use of communication media such as, for distributing newspapers or print media, the use of technologies such as radio, television and so on to attract people to participate in political activities [8][9].

According Setiadi and Kolip [4] in his book Introduction to Political Sociology that political participation can be divided into three dimensions, namely: 1) active participation; 2) passive participation; 3) participation inactive (inactive). In general [10] it can be distinguished that active participation are activities that are "affecting" the input process is political, such as petitioning, demonstrations, contacts with government officials, active members, or board of political parties and propose alternative political decisions in contrast to public policy made by the government, Passive political participation is an act of "carrying out" political output, such as obey the law, pay taxes, and maintaining order and security, whereas the active political participation is not an act not to do anything, like do not choose,

Characters different voters with voters who have experienced, It is described by Setiajid [11], namely: 1) have never been selection or determination vote in the polling station, 2) do not have experience selecting, 3) have a high enthusiasm, 4) less rational, 5) voters the young are still turbulent and spirit, which if not controlled will have an effect on social conflicts in the elections, 6) were subjected to election participants because the amount is quite large, 7) has a curiosity, to try and participate in the elections even though sometimes with a variety of different backgrounds. 


\section{Methods}

This study used a qualitative approach by Denzin and Lincoln in Satori [12] "Qualitative research is research that uses the natural background, with the intention of interpreting phenomena and done by involving a variety of methods exist". On the other hand, qualitative research is a subjective study because researchers relied on the interpretation of the data analysis process.

In carrying out this study, the unit of analysis is the study Cikole voters in the district of Sukabumi. In a qualitative study did not use the population but by Spardley called "Social Situation" or social situation that consists of three elements: places, actors and activities that interact synergistically. Qualitative research departs from particular cases that exist in certain social situations and the study results would not be imposed on the population, but transferred to another place on the social situation in the cases studied [13]. As for the the informant is someone who really knows a particular problem or issue from which to obtain information that is clear, accurate and precise. Determination of informants in this study using nonprobability sampling with purposive sampling method, which is a technique of determining the subject/object to the purpose. Because the purpose of the object to be studied qualitative research has been ascertained, therefore, has become a topic of consideration in accordance with the study, researchers chose a subject / object as a unit of analysis. Researchers chose the analysis unit with a need's basis.

The data collection technique is the most strategic step in the research. Data collection techniques used in this research is observation, interviews, documentation and triangulation. The fourth technique used to obtain data and information on the political participation of voters in the city of Sukabumi.

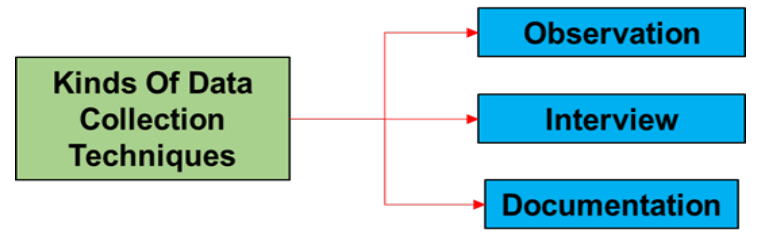

Fig. 2. Data Collection Technique

Inductive data analysis technique based on the facts found. In the framework of this study researchers used the data analysis of the data analysis focused since and during the collection process in the field with the data obtained.

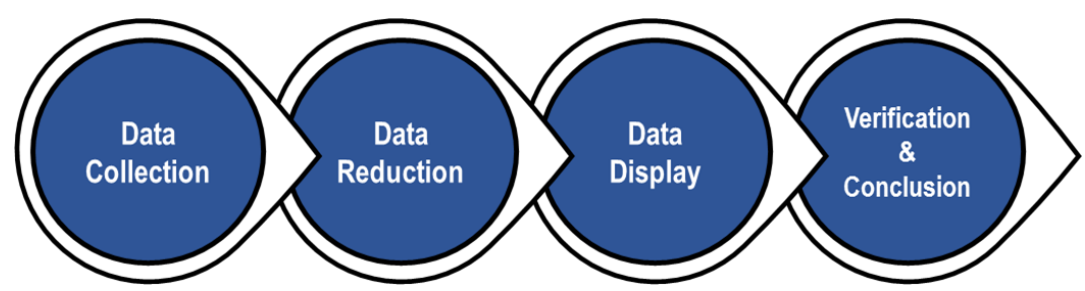

Fig. 3. Data Analysis Flow 


\section{Discussion}

The number of voters in the district Cikole. Data obtained from the Commission that the number of voters in the election of Mayor and Deputy Mayor of Sukabumi in 2018 there were 4,978 voters consisted of 2,509 male voters and 2,464 female registered voters in the DPT (Fixed Voter List) and DPTb (Additional Voter List). Can be described as follows:

Table 1. Number of Starter Voters in District Cikole 2018

\begin{tabular}{|c|l|c|c|c|c|c|c|}
\hline \multirow{2}{*}{ No } & \multirow{2}{*}{ Gender } & \multicolumn{6}{|c|}{ Urban Village } \\
\cline { 3 - 8 } & & Cikole & Selabatu & Mount Parang & Kebonjati & Cisarua & Subangjaya \\
\hline 1 & Man & 248 & 388 & 135 & 280 & 754 & 704 \\
\hline 2 & Woman & 245 & 416 & 135 & 262 & 715 & 691 \\
\hline \multicolumn{2}{r}{ Total } & $\mathbf{4 9 3}$ & $\mathbf{8 0 4}$ & $\mathbf{2 7 0}$ & $\mathbf{5 4 2}$ & $\mathbf{1 4 6 9}$ & $\mathbf{1 3 9 5}$ \\
\hline
\end{tabular}

Source: General Election Commissions of Sukabumi.

Number of voters in the district Cikole many as 4,973, consisting of 2,509 men present cast his vote as many as 1,872 and 2,464 female voters of the present cast his vote as much as 2,032. Can be calculated the total number of voters who are present to vote as many as 3,904 or about $78.5 \%$ and first-time voters who did not attend as many as 1,069 , or about $21.49 \%$.

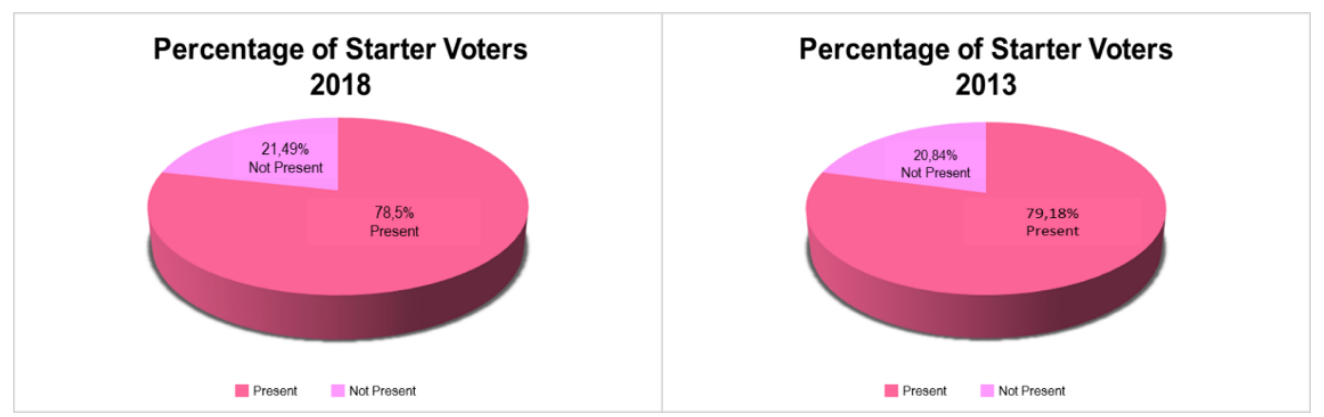

Fig. 4. Percentage of Starter Voters 2018 and 2013 (Source: General Election Commissions of Sukabumi).

Compared with the year 2013 there was a slight decline in the participation of voters in 2018 . In 2013 of the number of voters as much as 4706 that use their rights as much as 3,725 or approximately $79.15 \%$ and first-time voters who did not attend as many as 981 , or about $20.84 \%$.

After data collection is considered sufficient and fulfill what they want the next process is to reduce the data collected. The process of generating the data reduction subject matter and focus on the important things related to the participation of voters in the district Cikole the election of Mayor and Deputy Mayor of Sukabumi, who then searched the theme and pattern. It is important staple and it covers the role of each informant, the informant responses, and alignments informant against the phenomena that occur. The next process is the presentation of the data is done by classifying the various variables that factor into supporting political participation by Milbarth in Maran affecting the political participation of voters in the district Cikole the election of Mayor and Deputy Mayor of Sukabumi, 2018 which includes four factors. 
From the whole answer informant researchers interpret personal characteristics voters are still largely consciousness to participate in the election of Mayor and Deputy Mayor of Sukabumi, 2018, this is not surprising because the levels of participation are varied. The concept of political participation one of which covers the so-called political apathy. According to informants 1, 2, and 3 characters of individual voters as nice as they look enthusiastic when they disseminate to schools alone, in contrast to the responses of informants from 5 to 16 , as voters they admit they lack the awareness to participate in political life, while according to the organizers informant $4 \mathrm{sub}$ district level is still less responsive to voters are not recorded. Voters that voting is their own individual characteristics of good and has concern for political activity. Due to the participation of the eternal is the growing participation of consciousness itself,

Based on data from voters in the district Cikole enrolled in the DPT and DPTb are 4,973 voters consisted of 2,509 men and 2,464 women. Voters who came to the polls to exercise their voting rights as much as 3,904 voters, or about $78.5 \%$, which consisted of 1,872 men and 2,032 women, can be seen from the number of voters that were not present to the polls as many as 1,069 voters, or about $21,49 \%$. This shows lack of enthusiasm of voters in the district Cikole resulting in decreased levels of political participation when compared to the elections in 2013, with the number of voters who comes to the polling station 4706 as many as 3,725 , or about $79.15 \%$. Although politics has given stimuli but lacking the character of the individual, it still affects the participation of voters. Low political participation generally indicates that people are less put appreciation or interest in state activities. And if the higher levels of political participation indicate that people follow, understand, and engage in state activities.

Based on the opinion of a good informant from the organizer or from voters about the social characteristics, the researchers interpret that voters were given voting rights in general is influenced by social characteristics. It is confirmed from the statement of voters who finished voting say that they have not fully know who they would choose, they confessed their choice based solely on the advice of the surrounding environment, including the family. But there are also voters who exercise their right to vote because given the responsibility as a committee and voters who see the candidates of their vision and mission, not the influence of the surrounding environment. From the recognition of some informants known that political participation of voters are still heavily influenced by others.

Based on the statement of the 12 informants who have used their right to vote, as well as see the environmental situation in the district Cikole, the researchers interpret the situation of the political environment in the district Cikole included into the category of safe and conducive, so that all people, especially first-time voters are able to participate actively in the process of the election of Mayor and Deputy Mayor of Sukabumi in 2018.

Based on the above it can be concluded that the stimulus provided by the organizers, community and social characteristics conducive situation during the voting process, influence on the attitude of voters to participate in active political participation of Mayor and Deputy Mayor elect.

On the other hand, this study found the phenomenon that voters still do not understand the importance of political participation for sustainable development next five years, thus preferring passive in politics by not doing anything. Characteristics of such voters was surely going to be a barrier for the electoral process and improving the quality of the election results. 


\section{Conclusions and Recommendations}

Based on the research that has been described by previous researchers on political participation rate in the District Voters Beginner Cikole of Sukabumi (Studies on Election Mayor of the Year 2018), with notice or reference to the theory Milbarth namely:

a) The existence of stimulants politics, stimulus provided by the organizers and KPU officials were optimal, voters generally already know about the candidates for Mayor and Deputy Mayor of Sukabumi in 2018, they knew of socialization conducted by the Commission in the form of banners, social media, sticker stick to the walls of houses, as well as a hiking activity organized by the Commission;

b) The personal character of a person, the individual characters voters still needs to be improved, because most still lack of thinking, understanding and less concerned about the political activities, so they opted to run preoccupations rather than taking the time to participate in the political exercise their right to vote in the election of Mayor and Deputy Mayor of Sukabumi, 2018;

c) Social characteristics, Proven voters strongly influenced by the environment in using their voting rights and in determining the choice tend to still follow the advice of the surrounding environment;

d) The situation and the political environment, environmental conditions Subdistrict politically Cikole can be categorized as safe and conducive. Every informant who use their voting rights reveals that nothing has happened that makes voters reluctant to participate, since before the election until the end of the counting of votes in District Cikole situation free of money politics.

Factors supporting the increase Beginner Voter Participation in District Cikole (Studies on Election Mayor of Sukabumi, 2018) according to Milbart theory include: (1) The existence of political Stimulators (2) Social Characteristics (3) Situation and Political Environment.

The factors that need to be improved is the personal character of a person, which is referred to here is the character of the individual voters who need to be grown awareness to actively participate in political activities.

\subsection{Theoretical Advice}

Based on the theoretical aspects of researchers suggest further research related to efforts to raise public awareness, especially for first-time voters to want to participate actively politics.

\subsection{Practical Advice}

To increase the political participation of voters in the district Cikole, then there are some suggestions that researchers propose that:

a) The support of the family to remind the importance of voting, by introducing an early age the importance of political participation for the betterment of the nation. So that voters are accustomed to making decisions for the future;

b) For PPK (District Election Committee) officials at district level, in the process of voter data collection needs to be improved because many voters are not recorded at the time of the election of Mayor of Sukabumi in 2018;

c) Further enhanced efforts to provide political stimuli that attract voters to raise their awareness level participated actively through social media such as creating advertising (pop-up), seeking endorsement to create an ad in a game, playstore and more. 


\section{References}

[1] S. Damsar, "Pengantar Sosiologi Politik," Jakarta: Kencana Prenada, 2010.

[2] K. Faulks, "Political Socuology: A Critical Introduction, diterjemahkan Helmi Mahadi dan Shohifullah (2012), Sosiologi Politik Pengantar Kritis,” Bandung Nusa Media, 2012.

[3] R. Imawan, Menjadi Pemilih yang Baik dalam Pemilu 2004. Yogyakarta: Universitas Gajah Mada, 2003

[4] E. M. Setiadi and U. Kolip, Pengantar sosiologi politik. Kencana, 2013.

[5] R. R. Maran, Pengantar sosiologi politik. PT Rineka Cipta, 2001.

[6] P. S. Chaniago, "Evaluasi Pilkada Pelaksanaan Pilkada Serentak Tahun 2015," Polit. Indones. Indones. Polit. Sci. Rev., vol. 1, no. 2, pp. 196-211, 2016.

[7] H. Eko, "Sosiologi Politik," UNES. Semarang, 2008.

[8] R. Harun and A. P. Sumarno, "Komunikasi politik sebagai suatu pengantar," Bandung Mandar Maju, 2006.

[9] Sodikin, Hukum Pemilu Pemilu Sebagai Praktek Ketatanegaraan. Jakarta: Gramata Publishing, 2014.

[10] S. Syarbaini, “Dkk. 2002 Sosiologi dan Politik.” Jakarta: Ghalia Indonesia.

[11] Setiajid, "Orientasi Politik yang Mempengaruhi Pemilih Pemula dalam Menggunakan Hak Pilihnya pada Pemilihan Walikota Semarang Tahun 2010 (Studi Kasus Pemilih Pemula di Kota Semarang)," Integralistik, vol. 22, no. 1, 2011.

[12] S. Djam'an and K. Aan, "Metodologi Penelitian Kualitatif," Bandung Alf., 2011.

[13] Sugiyono, Metode Penelitian Kuantitatif, Kualitatif dan R\&D. Bandung: Alfabeta, 2008. 